\title{
Determining the route for the purpose light vehicles testing in Real Driving Emissions (RDE) test
}

In the regulations concerning approval of light vehicles starting from September 2019 it will be necessary to conduct exhaust emissions tests both on a chassis dynamometer and for real driving emissions. It is a legislative requirement set forth in EU regulations for the purpose of the RDE (Real Driving Emissions) procedure.

To decide on the RDE route for the purpose of the LV exhaust emissions tests many requirements must be fulfilled, regarding for example external temperature and the topographic height of the tests, driving style (driving dynamic parameters), trip duration, length of respective test sections (urban, rural, motorway, etc.). The works on outlining RDE routes are continued across the country in various research centres. Specifying the RDE route for test purposes, i.e. works in which the authors of this article are actively involved, has become a major challenge for future approval surveys concerning the assessment of hazardous emissions from light vehicles and for development studies focusing on - for example - the consumption of energy in electric and hybrid vehicles.

The test route has been chosen to ensure that the test is performed on a continual basis. Data were recorded on a constant basis with the minimum duration of the test achieved. The test involved light vehicles and PEMS device for measuring the exhaust emissions, vehicle's speed, completed route, etc. The device was installed in such manner as to ensure that its impact on the exhaust emissions from the tested vehicle and on the device's operation is the least.

The vehicle load was consistent with the requirements of the standard and included the aforesaid measurement device, the driver and the operator of PEMS. The tests were carried out on working days. The streets and roads used for the tests were hard-surfaced. Measurements were performed in accordance with the requirements of RDE packages (Package 1-4), i.e. taking into account - among others - the engine cold start.

The article discusses the method of outlining the test route fulfilling the specific requirements for RDE testing. Chosen results of exhaust emissions from a passenger car with a spark-ignition engine along the defined RDE test route have been provided.

The tests discussed in the article are introductory in the area of RDE tests and provide an introduction into further studies of exhaust emissions and energy consumption in real driving conditions in conventional vehicles and vehicles with alternative engines, e.g. hybrid and electric vehicles.

Key words: RDE, vehicle, transport, passenger cars, test, ecology, homologation

\section{Introduction}

The approval process of light vehicles in the European Union comprises a procedure for the measurement of real driving emissions generated by those vehicles. In accordance with the requirements (Commission Regulation (EU) no. 582/2011, Commission Regulation (EU) no. 2018/932) for all new approvals the emissions of CO, THC, NMHC, $\mathrm{CH}_{4}, \mathrm{NO}_{\mathrm{x}}$ is measured in RDE, which cannot exceed 1.5 times the maximum Euro VI limit [1-4].

The parameters of road tests cannot be any parameters. It is necessary to select adequately the test route. The route must include driving in urban, rural and motorway areas. It is only one of the many requirements that must be met. The scope of those requirements is presented in Table 1.

\section{Moving Averaging Window method for exhaust emissions}

The Moving Averaging Window method provides an insight on the real-driving emissions (RDE) occurring during the test at a given scale. The test is divided in subsections (windows) and the subsequent statistical treatment aims at identifying which windows are suitable to assess the vehicle RDE performance.
The "normality" of the windows is conducted by comparing their $\mathrm{CO}_{2}$ distance-specific emissions with a reference curve. The test is complete when the test includes a sufficient number of normal windows, covering different speed areas (urban, rural, motorway). It consists of the following steps:

- calculation of emissions by sub-sets or "windows,

- identification of normal windows,

- verification of test completeness and normality,

- calculation of emissions using the normal windows,

- specifying dynamic trip parameters.

The instantaneous emissions must be integrated using a Moving Averaging Window method, based on the reference $\mathrm{CO}_{2}$ mass (Fig. 2). The principle of the calculation is as follows: the mass emissions are not calculated for the complete data set, but for sub-sets of the complete data set, the length of these sub-sets being determined so as to match the $\mathrm{CO}_{2}$ mass emitted by the vehicle over the reference laboratory cycle (WLTC). The moving average calculations are conducted with a time increment corresponding to the data sampling frequency (usually $1 \mathrm{~Hz}$ ). These sub-sets used to average the emissions data are referred to as "averaging windows". The calculation described in the present point may be run from the last point (backwards) or from the first point (forward). 
Table 1. Specific requirements regarding RDE tests [1-4]

\begin{tabular}{|c|c|}
\hline Parameter & Requirements \\
\hline \multirow[t]{3}{*}{ Ambient temperature $\left(\mathrm{T}_{\mathrm{z}}\right)$} & $-\quad$ normal range: $0^{\circ} \mathrm{C} \leq \mathrm{T}_{\mathrm{z}}<30^{\circ} \mathrm{C}$ \\
\hline & - lower extended range: $-7^{\circ} \mathrm{C} \leq \mathrm{T}_{\mathrm{z}}<0^{\circ} \mathrm{C}$ \\
\hline & - $\quad$ upper extended range: $30^{\circ} \mathrm{C}<\mathrm{T}_{\mathrm{z}} \leq 35^{\circ} \mathrm{C}$ \\
\hline \multirow[t]{2}{*}{ Topographic height of test areas (h) } & - $\quad$ normal range: $\mathrm{h} \leq 700 \mathrm{~m}$ a.s.l. \\
\hline & - $\quad$ extended range: $700<\mathrm{h} \leq 1300 \mathrm{~m}$ a.s.1. \\
\hline \multirow{3}{*}{$\begin{array}{l}\text { Impact of external weather and road parame- } \\
\text { ters and the driving style }\end{array}$} & - accumulated height increase: less than $1200 \mathrm{~m} / 100 \mathrm{~km}$ \\
\hline & - $\quad$ (RPA): greater than $\mathrm{RPA}_{\min }$ (in all driving conditions) \\
\hline & - product of acceleration and speed $\left(\mathrm{v} \cdot \mathrm{a}_{\mathrm{pos}}\right)$ : less than $\mathrm{v} \cdot \mathrm{a}_{\text {pos min }}$ (in all driving conditions) \\
\hline \multirow[t]{2}{*}{ Thermal condition of the vehicle prior to tests } & - cold start: coolant less than $70^{\circ} \mathrm{C}$, time of at least $300 \mathrm{~s}$ \\
\hline & - $\quad$ emission upon cold start not included in RDE test \\
\hline Single vehicle downtime & - $\quad$ no more than $180 \mathrm{~s}$ \\
\hline Exhaust after-treatment system's operation & $\begin{array}{l}\text { - } \\
\text { ingle regeneration of PM filter can result in RDE test repetition; two regenerations are } \\
\text { included in the results of exhaust emissions in RDE test }\end{array}$ \\
\hline Driving comfort system operation & - $\quad$ used normally according to purpose (e.g. air-conditioning system) \\
\hline Vehicle load & $\begin{array}{l}\text { - weight of vehicle: driver (and passenger) and test equipment; } \max \text {. load }<90 \% \text { of the } \\
\text { sum of weight of passengers and vehicle's usable mass }\end{array}$ \\
\hline Test requirement & $-\quad$ duration $90-120 \mathrm{~min}$ \\
\hline \multirow[t]{5}{*}{ Requirements for the urban test part } & $-\quad 29-44 \%$ of the entire test length \\
\hline & - distance more than $16 \mathrm{~km}$ \\
\hline & $-\quad$ speed $(\mathrm{v}): \mathrm{v} \leq 60 \mathrm{~km} / \mathrm{h}$ \\
\hline & - $\quad$ average speed: $15-40 \mathrm{~km} / \mathrm{h}$ \\
\hline & - break: $6-30 \%$ of the total urban time \\
\hline \multirow[t]{3}{*}{ Requirements for the rural part } & $-\quad 23-43 \%$ of the entire test length \\
\hline & - distance: greater than $16 \mathrm{~km}$ \\
\hline & - vehicle's speed (v): $60 \mathrm{~km} / \mathrm{h}<\mathrm{v} \leq 90 \mathrm{~km} / \mathrm{h}$ \\
\hline \multirow[t]{5}{*}{ Requirements for the motorway part } & $-\quad 23-43 \%$ of the entire test length \\
\hline & - distance: greater than $16 \mathrm{~km}$ \\
\hline & _ vehicle's speed (v): v > $90 \mathrm{~km} / \mathrm{h}$ \\
\hline & - driving speed of more than $100 \mathrm{~km} / \mathrm{h}$ for at least $5 \mathrm{~min}$ \\
\hline & - driving speed of more than $145 \mathrm{~km} / \mathrm{h}$ for at least $3 \%$ of the time \\
\hline
\end{tabular}

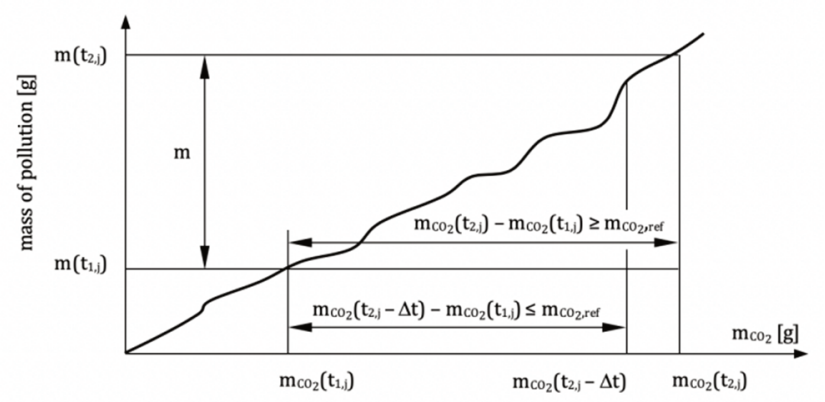

Fig. 2. Definition of $\mathrm{CO}_{2}$ mass based averaging windows [1-4]

Duration of $i$-window average $\left(t_{2, j}-t_{1, j}\right)$ is determined according to the following formula (Fig. 2):

$$
\mathrm{m}_{\mathrm{CO}_{2}}\left(\mathrm{t}_{2, \mathrm{j}}\right)-\mathrm{m}_{\mathrm{CO}_{2}}\left(\mathrm{t}_{1, \mathrm{j}}\right) \geq \mathrm{m}_{\mathrm{CO} 2 \text {,ref }}
$$

where: $\mathrm{m}_{\mathrm{CO}_{2}}\left(\mathrm{t}_{\mathrm{i}, \mathrm{j}}\right)$ - is the $\mathrm{CO}_{2}$ mass measured between the test start and time $\left(\mathrm{t}_{\mathrm{i}, \mathrm{j}}\right),[\mathrm{g}] ; \mathrm{m}_{\mathrm{CO}_{2} \text {,ref }}-$ is the half of the $\mathrm{CO}_{2}$ mass [g] emitted by the vehicle over the WLTP cycle (type I test, including cold start); $\mathrm{t}_{2, \mathrm{j}}$ - shall be selected such as:

$$
\mathrm{m}_{\mathrm{CO} 2}\left(\mathrm{t}_{2, \mathrm{j}}-\Delta \mathrm{t}\right)-\mathrm{m}_{\mathrm{CO}_{2}}\left(\mathrm{t}_{1, \mathrm{j}}\right)<\mathrm{m}_{\mathrm{CO} 2, \text { ref }} \leq \mathrm{m}_{\mathrm{CO}_{2}}\left(\mathrm{t}_{2, \mathrm{j}}\right)-\mathrm{m}_{\mathrm{CO} 2}\left(\mathrm{t}_{1, \mathrm{j}}\right)
$$

where $\Delta \mathrm{t}$ is the data sampling period (1 $\mathrm{s}$ or less).

The reference points $P_{1}, P_{2}$ and $P_{3}$ (Fig. 3) required to define the curve shall be established as follows:

- $\mathrm{P}_{1}: \mathrm{v}_{\mathrm{P}_{1}}=19 \mathrm{~km} / \mathrm{h}$ (average speed of the 1 Low Speed phase of the WLTP cycle),

- $\mathrm{b}_{\mathrm{CO}_{2}, \mathrm{P}_{1}}$ - on-road emission of $\mathrm{CO}_{2}[\mathrm{~g} / \mathrm{km}]$ of 1 Low Speed phase of the WLTC phase increased by $20 \%$,

- $\mathrm{P}_{2}: \mathrm{v}_{\mathrm{P}_{2}}=56.6 \mathrm{~km} / \mathrm{h}$ (average speed of the 3 High Speed phase of the WLTP cycle),

- $\mathrm{b}_{\mathrm{CO}_{2}, \mathrm{P} 2}$ - on-road emission of $\mathrm{CO}_{2}[\mathrm{~g} / \mathrm{km}]$ of 3 Low Speed phase of the WLTC phase increased by $10 \%$,

- $P_{3}: v_{P_{3}}=92.3 \mathrm{~km} / \mathrm{h}$ (average speed of the 4 Extra High Speed phase of the WLTP cycle),

- $\mathrm{b}_{\mathrm{CO}_{2}, \mathrm{P} 3}=$ on-road emission of $\mathrm{CO}_{2}[\mathrm{~g} / \mathrm{km}]$ of 4 Low Speed phase of the WLTC phase increased by $5 \%$.

The $\mathrm{CO}_{2}$ emissions are calculated as a function of the average speed using two linear sections $\left(\mathrm{P}_{1}, \mathrm{P}_{2}\right)$ and $\left(\mathrm{P}_{2}, \mathrm{P}_{3}\right)$. 
The section $\left(\mathrm{P}_{2}, \mathrm{P}_{3}\right)$ is limited to $145 \mathrm{~km} / \mathrm{h}$ on the vehicle speed axis.

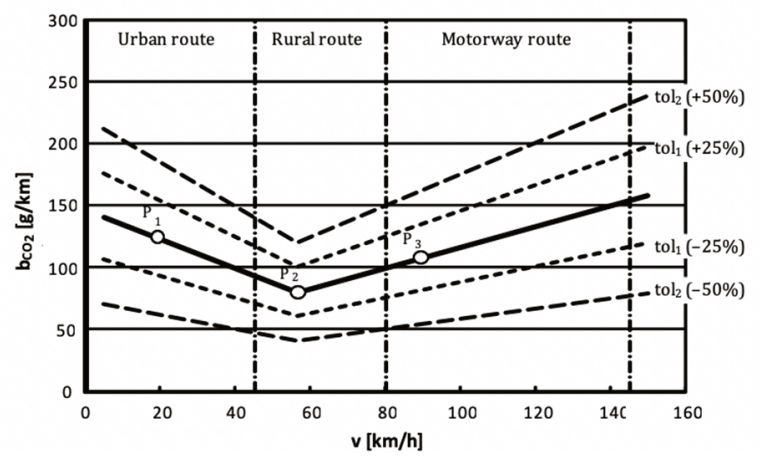

Fig. 3. Vehicle $\mathrm{CO}_{2}$ characteristic curve

Urban windows are characterized by average vehicle ground speeds smaller than $45 \mathrm{~km} / \mathrm{h}$, rural windows are characterized by average vehicle ground speeds greater than or equal to $45 \mathrm{~km} / \mathrm{h}$ and smaller than $80 \mathrm{~km} / \mathrm{h}$, motorway windows are characterized by average vehicle ground speeds greater than or equal to $80 \mathrm{~km} / \mathrm{h}$ and smaller than $145 \mathrm{~km} / \mathrm{h}$. The primary tolerance and the secondary tolerance of the vehicle $\mathrm{CO}_{2}$ characteristic curve are respectively tol $_{1}=25 \%$ and $\operatorname{tol}_{2}=50 \%$. The test shall be complete when it comprises at least $15 \%$ of urban, rural and motorway windows, out of the total number of windows. The test shall be normal when at least $50 \%$ of the urban, rural and motorway windows are within the primary tolerance defined for the characteristic curve. If the specified minimum requirement of $50 \%$ is not met, the upper positive tolerance $\operatorname{tol}_{1}$ may be increased by steps of $1 \%$ until the $50 \%$ of normal windows target is reached. When using this mechanism, tol $_{1}$ shall never exceed $30 \%$.

Having ascertained that the test is complete, the weighing factor for each window shall be determined in the following tolerance ranges:

- if the window falls within the $1^{\text {st }}$ degree tolerance, i.e.:

$$
\mathrm{b}_{\mathrm{CO}_{2}}\left(1-\frac{\text { tol }_{1}}{100}\right) \leq \mathrm{b}_{\mathrm{CO}_{2}, \mathrm{i}} \leq \mathrm{b}_{\mathrm{CO}_{2}}\left(1+\frac{\text { tol }_{1}}{100}\right)
$$

the weighing factor shall be equal 1 .

- if the window falls within the tolerance range from $+25 \%$ to $+50 \%$, i.e.:

$$
\mathrm{b}_{\mathrm{CO}_{2}}\left(1+\frac{\text { tol }_{1}}{100}\right) \leq \mathrm{b}_{\mathrm{CO}_{2}, \mathrm{i}} \leq \mathrm{b}_{\mathrm{CO}_{2}}\left(1+\frac{\text { tol }_{2}}{100}\right)
$$

its weighing factor shall be determined with the following formula:

$$
\mathrm{w}=\mathrm{k}_{11} \mathrm{~h}+\mathrm{k}_{12}
$$

where: $\mathrm{k}_{11}=\frac{1}{\mathrm{tol}_{1}-\mathrm{tol}_{2}}, \mathrm{a} \mathrm{k}_{12}=\frac{\mathrm{tol}_{2}}{\mathrm{tol}_{2}-\mathrm{tol}_{1}}$,

- if the window falls within the tolerance range from $-50 \%$ to $-25 \%$, i.e.:

$$
\mathrm{b}_{\mathrm{CO}_{2}}\left(1-\frac{\text { tol }_{2}}{100}\right) \leq \mathrm{b}_{\mathrm{CO}_{2}, \mathrm{i}} \leq \mathrm{b}_{\mathrm{CO}_{2}}\left(1-\frac{\text { tol }_{1}}{100}\right)
$$

its weighing factor shall be determined with the following formula:

$$
\mathrm{w}=\mathrm{k}_{21} \mathrm{~h}+\mathrm{k}_{22}
$$

where: $\mathrm{k}_{21}=\frac{1}{\mathrm{tol}_{2}-\mathrm{tol}_{1}}, \mathrm{a} \mathrm{k}_{22}=\frac{\mathrm{tol}_{2}}{\mathrm{tol}_{2}-\mathrm{tol}_{1}}$,

- if the window falls below tolerance range $-50 \%$ or above $+50 \%$, i.e.:

$$
\mathrm{b}_{\mathrm{CO}_{2}, \mathrm{i}} \leq \mathrm{b}_{\mathrm{CO}_{2}}\left(1-\frac{\mathrm{tol}_{2}}{100}\right) \text { or } \mathrm{b}_{\mathrm{CO}_{2}, \mathrm{i}} \geq \mathrm{b}_{\mathrm{CO}_{2}}\left(1+\frac{\mathrm{tol}_{2}}{100}\right)(8)
$$

its weighing factor is $\mathrm{w}=0$.

The value of $\mathrm{h}$ for every window is determined based on the following formula:

$$
\mathrm{h}=100\left(\frac{\mathrm{b}_{\mathrm{CO}_{2, \mathrm{i}}}-\mathrm{b}_{\mathrm{CO}_{2}}}{\mathrm{~b}_{\mathrm{CO}_{2}}}\right)
$$

After the weighing factor for every window is determined, it is marked on the chart where every weighing factor (w) is marked on the y axis, tolerance percentage (h) on $\mathrm{x}$ axis (Fig. 4).

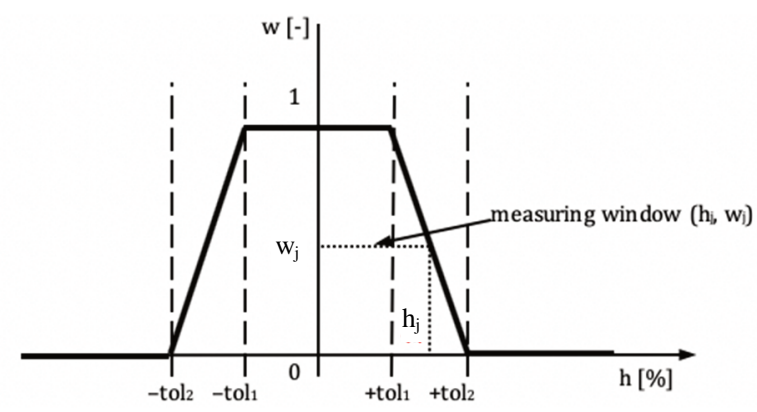

Fig. 4. Averaging window weighing function [1-4]

After all those steps are performed, the $\mathrm{CO}_{2}$ on-road emissions for every window are illustrated on the characteristic curve chart (Fig. 5).

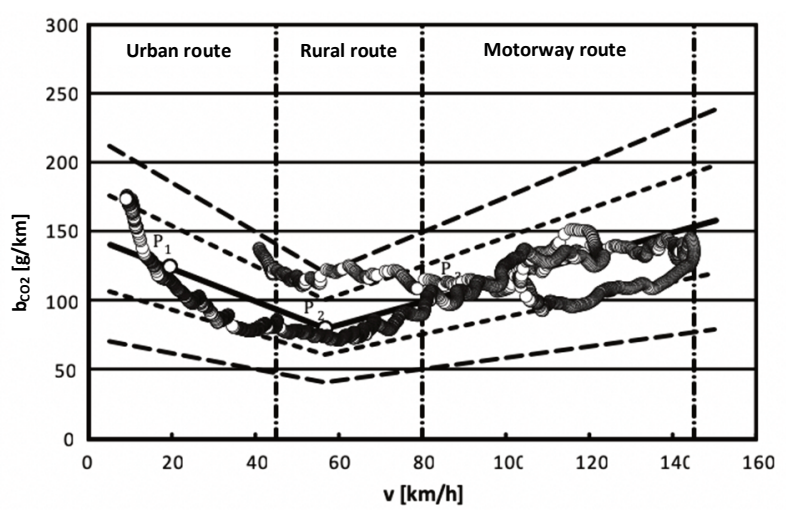

Fig. 5. Vehicle $\mathrm{CO}_{2}$ characteristic curve with $\mathrm{CO}_{2}$ emissions in respective windows, during on-road tests [1-4] 
Next the severity indices shall be calculated separately for the urban (m), rural (p) and motorway (a) categories by summarising windows for a particular category $\left(\mathrm{h}_{\mathrm{k}}\right)$ and dividing by the total number $(\mathrm{N})$, e.g. for the urban category:

$$
\mathrm{u}=\frac{\sum \mathrm{h}_{\mathrm{k}}}{\mathrm{N}}, \mathrm{k}=\mathrm{m}, \mathrm{p}, \mathrm{a}
$$

and the complete trip:

$$
\mathrm{u}=\frac{\mathrm{f}_{\mathrm{m}} \mathrm{h}_{\mathrm{m}}+\mathrm{f}_{\mathrm{p}} \mathrm{h}_{\mathrm{p}}+\mathrm{f}_{\mathrm{a}} \mathrm{h}_{\mathrm{a}}}{\mathrm{f}_{\mathrm{m}}+\mathrm{f}_{\mathrm{p}}+\mathrm{f}_{\mathrm{a}}}
$$

where: $\mathrm{f}_{\mathrm{m}}=0.34, \mathrm{f}_{\mathrm{p}}=0.33, \mathrm{a} \mathrm{f}_{\mathrm{a}}=0.33$.

In the end the distance-specific emissions in $[\mathrm{mg} / \mathrm{km}]$ are calculated for the complete trip each gaseous pollutant in the following way:

$$
b_{j}=1000 \cdot \frac{f_{m} b_{j, m}+f_{p} b_{j, p}+f_{a} b_{j, a}}{f_{m}+f_{p}+f_{a}}
$$

and for the on-road emission of particulate matter:

$$
b_{P N}=\frac{f_{m} b_{P N, m}+f_{p} b_{P N, p}+f_{a} b_{P N, a}}{f_{m}+f_{p}+f_{a}}
$$

To determine dynamic trip parameters the following must be determined: value of 95 centile of the product of driving speed and positive acceleration greater than 0.1 $\mathrm{m} / \mathrm{s}^{2}$ (expressed in $\mathrm{m}^{2} / \mathrm{s}^{3}$ ) and relative positive acceleration (expressed in $\mathrm{m} / \mathrm{s}^{2}$ ) for urban, rural and motorway shares.

The value of the $95^{\text {th }}$ centile of the product $\left(v \cdot a_{+}\right)-$ formulated as $\left(\mathrm{v} \cdot \mathrm{a}_{+}\right)_{\mathrm{k}_{\_}[95]}-$ is determined in the following manner: value of products $\left(\mathrm{v} \cdot \mathrm{a}_{+}\right)_{\mathrm{i}, \mathrm{k}}$ in every test part $(\mathrm{k}-$ urban, rural and motorway share) is categorised in a growing order for all data sets of $a_{i, k} \geq 0.1 \mathrm{~m} / \mathrm{s}^{2}$ (number of data sets must be greater than 150) and the total number of windows $\mathrm{N}_{\mathrm{k}}$ is determined.

In the next step the centile values are allocated to the product $\left(\mathrm{v} \cdot \mathrm{a}_{+}\right)_{\mathrm{i}, \mathrm{k}}$ in the following manner: the lowest value of the product $\left(\mathrm{v} \cdot \mathrm{a}_{+}\right)$has centile of $1 / \mathrm{N}_{\mathrm{k}}$, the second lowest $-2 / N_{k}$, the third lowest $-3 / N_{k}$, and the highest value $\mathrm{N}_{\mathrm{k}} / \mathrm{N}_{\mathrm{k}}=100 \%$. Value $\left(\mathrm{v} \cdot \mathrm{a}_{+}\right)_{\mathrm{k}_{-}[95]}$ stands for $\left(\mathrm{v} \cdot \mathrm{a}_{+}\right)_{\mathrm{i}, \mathrm{k}}$, for which $\mathrm{j} / \mathrm{N}_{\mathrm{k}}=95 \%(\mathrm{j}$ - successive value of product of speed and positive acceleration). If $\mathrm{j} / \mathrm{N}_{\mathrm{k}}=95 \%$ cannot be achieved, then $\left(v \cdot a_{+}\right)_{k_{-}[95]}$ is determined based on line interpolation of successive samples $\mathrm{j}$ and $(\mathrm{j}+1)$, for which $\mathrm{j} / \mathrm{N}_{\mathrm{k}}<95 \%$ and $(\mathrm{j}+1) / \mathrm{N}_{\mathrm{k}}>95 \%$.

The validity of the trip is verified for every urban, rural and motorway share. If the value of $\left(\mathrm{v} \cdot \mathrm{a}_{+}\right)_{\mathrm{k}_{-}[95]}$ meets the equation for every test step (Fig. 6a):

$$
\begin{aligned}
& \left(\mathrm{v} \cdot \mathrm{a}_{+}\right)_{\mathrm{k}_{-}[95]}<0,136 \cdot \overline{\mathrm{v}}_{\mathrm{k}}+14,4 \text { for } \overline{\mathrm{v}}_{\mathrm{k}} \leq 74,6 \mathrm{~km} / \mathrm{h}(15) \\
& \left(\mathrm{v} \cdot \mathrm{a}_{+}\right)_{\mathrm{k}_{-}[95]}<0,0742 \cdot \overline{\mathrm{v}}_{\mathrm{k}}+18,966 \text { for } \overline{\mathrm{v}}_{\mathrm{k}}>74,6 \mathrm{~km} / \mathrm{h}(16)
\end{aligned}
$$

the trip is valid.

RPA - relative positive acceleration for every step of the test is determined based on the following formula:

$$
\mathrm{RPA}_{\mathrm{k}}=\frac{\sum_{\mathrm{j}=1}^{\mathrm{N}_{\mathrm{k}}} \Delta \mathrm{t} \cdot\left(\mathrm{v} \cdot \mathrm{a}_{+}\right)_{\mathrm{j}, \mathrm{k}}}{\sum_{\mathrm{j}=1}^{\mathrm{L}} \mathrm{d}_{\mathrm{i}, \mathrm{k}}}
$$

where: $\mathrm{RPA}_{\mathrm{k}}$ - relative positive acceleration for urban, rural and motorway shares, $\mathrm{m} / \mathrm{s}^{2}, \Delta \mathrm{t}$ - data sampling period (1 s), $\mathrm{N}_{\mathrm{k}}$ - number of windows for urban, rural, and motorway shares with positive acceleration, $\mathrm{L}$ - total number of windows for urban, rural, and motorway shares.

If $\mathrm{RPA}_{\mathrm{k}}$ value meets the equation for every test step Eq. (14):

$$
\begin{gathered}
\mathrm{RPA}>-0,0016 \cdot \overline{\mathrm{v}}_{\mathrm{k}}+0,1755 \text { for } \overline{\mathrm{v}}_{\mathrm{k}} \leq 94,05 \mathrm{~km} / \mathrm{h} \\
\mathrm{RPA}>0,025 \text { for } \overline{\mathrm{v}}_{\mathrm{k}}>94,05 \mathrm{~km} / \mathrm{h}
\end{gathered}
$$

the trip is valid.

\section{Determing the test route}

Several driving trips were performed in order to outline the test route. Three test vehicles were used to perform the trips. Technical data of those vehicles are presented in Table 2 below.

Table 2. Parameters of vehicles used to delineate RDE route

\begin{tabular}{|l|c|c|c|}
\hline & Vehicle I & Vehicle II & Vehicle III \\
\hline Production year & 2017 & 2008 & 2017 \\
\hline Engine displacement & $1598 \mathrm{~cm}^{3}$ & $1798 \mathrm{~cm}^{3}$ & $1502 \mathrm{~cm}^{3}$ \\
\hline Drive unit power & $100 \mathrm{~kW}$ & $92 \mathrm{~kW}$ & $105 \mathrm{~kW}$ \\
\hline Type of fuel & Diesel oil & Petrol & Petrol \\
\hline Vehicle category & $\mathrm{M} 1$ & $\mathrm{M} 1$ & $\mathrm{M} 1$ \\
\hline Vehicle mass & $1375 \mathrm{~kg}$ & $1340 \mathrm{~kg}$ & $1690 \mathrm{~kg}$ \\
\hline
\end{tabular}

After every attempt to outline the trip route, an analysis of the resulting data was performed, based on which it was determined whether its requirements were met. PEMSSemtech DS measuring equipment - among others - was used for this purpose [5-7]. Table 3 and Table 4 presents parameters of the test trips.

Having fulfilled requirements for a route, a series of measurements was carried out to verify the accuracy of the obtained results. The outlined test route is shown in Fig. 6 below.
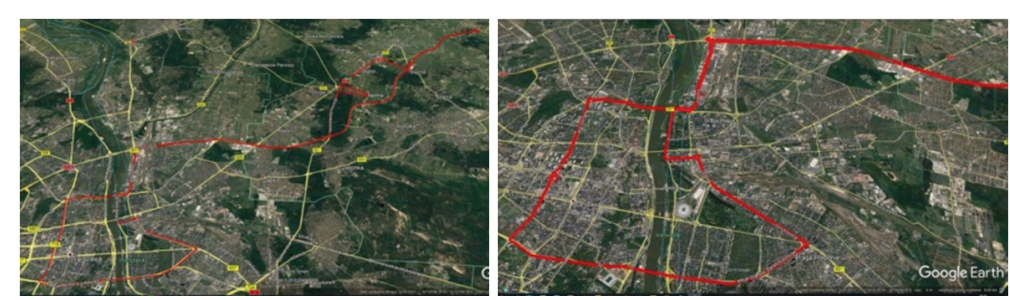

Fig. 6. Test route

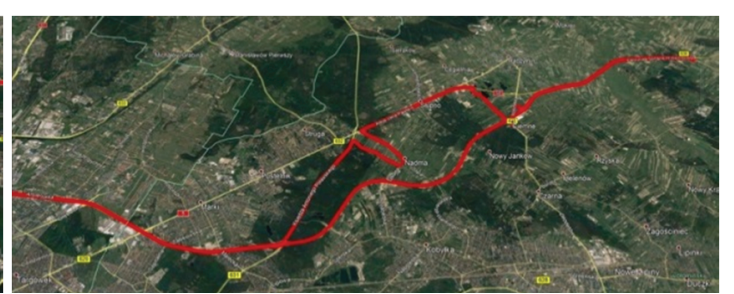


Determining the route for the purpose light vehicles testing in Real Driving Emissions (RDE) test

Table 3. RDE test parameters - test example (unfulfilled test)

\begin{tabular}{|c|c|c|c|}
\hline \multicolumn{4}{|c|}{ Test accuracy } \\
\hline Test parameter & Result & Requirement & Correctness \\
\hline Urban route $[\mathrm{km}]$ & 27.78 & $>16$ & Correct \\
\hline Rural route $[\mathrm{km}]$ & 20.76 & $>16$ & Correct \\
\hline Motorway route $[\mathrm{km}]$ & 14.49 & $>16$ & Incorrect \\
\hline Overall route $[\mathrm{km}]$ & 63.04 & $>48$ & Correct \\
\hline Urban share [\%] & 44.07 & $29-44$ & Incorrect \\
\hline Rural share [\%] & 32.94 & $33 \pm 10$ & Correct \\
\hline Motorway share [\%] & 22.99 & $33 \pm 10$ & Incorrect \\
\hline $\begin{array}{l}\text { Average speed in urban } \\
\text { route }[\mathrm{km} / \mathrm{h}]\end{array}$ & 31.80 & $15-40$ & Correct \\
\hline $\begin{array}{l}\text { Share of downtime } \\
\text { in urban route [\%] }\end{array}$ & 16.18 & $6-30$ & Correct \\
\hline $\begin{array}{l}\text { Trip time above } \\
100 \mathrm{~km} / \mathrm{h} \text { [min] }\end{array}$ & 7.13 & $>5$ & Correct \\
\hline $\begin{array}{l}\text { Max. driving speed } \\
{[\mathrm{km} / \mathrm{h}]}\end{array}$ & 126.00 & $<160$ & Correct \\
\hline $\begin{array}{l}\text { Trip time above } \\
145 \mathrm{~km} / \mathrm{h}\end{array}$ & 0.00 & $<3$ & Correct \\
\hline Duration of trip [min] & 77.97 & $90-120$ & Incorrect \\
\hline \multicolumn{4}{|c|}{ Dynamic test conditions } \\
\hline $\begin{array}{l}\text { Urban: number of data } \\
a>0.1 \mathrm{~m} / \mathrm{s}^{2}\end{array}$ & 956 & $>150$ & Correct \\
\hline $\begin{array}{l}\text { Rural: number of data } \\
a>0.1 \mathrm{~m} / \mathrm{s}^{2}\end{array}$ & 272 & $>150$ & Correct \\
\hline $\begin{array}{l}\text { Motorway: number } \\
\text { of data a }>0.1 \mathrm{~m} / \mathrm{s}^{2}\end{array}$ & 140 & $>150$ & Incorrect \\
\hline $\begin{array}{l}\text { Urban: average speed } \\
{[\mathrm{km} / \mathrm{h}]}\end{array}$ & 31.80 & & \\
\hline $\begin{array}{l}\text { Rural: average speed } \\
{[\mathrm{km} / \mathrm{h}]}\end{array}$ & 70.26 & & \\
\hline $\begin{array}{l}\text { Motorway: average } \\
\text { speed }[\mathrm{km} / \mathrm{h}]\end{array}$ & 111.24 & & \\
\hline $\begin{array}{l}\text { Urban: } 95^{\text {th }} \text { centile } \\
\text { V.a } a_{\text {pos }}\left[\mathrm{m}^{2} / \mathrm{s}^{3}\right]\end{array}$ & 12.27 & $<18.765$ & Correct \\
\hline $\begin{array}{l}\text { Rural: } 95^{\text {th }} \text { centile } \\
\text { V.a } a_{\text {pos }}\left[\mathrm{m}^{2} / \mathrm{s}^{3}\right]\end{array}$ & 16.42 & $<23.995$ & Correct \\
\hline $\begin{array}{l}\text { Motorway: } 95^{\text {th }} \text { centile } \\
\text { V.a } a_{\text {pos }}\left[\mathrm{m}^{2} / \mathrm{s}^{3}\right]\end{array}$ & 15.43 & $<27.220$ & Correct \\
\hline Urban: RPA [m/ $\left./ \mathrm{s}^{2}\right]$ & 0.14 & $>0.125$ & Correct \\
\hline Rural: RPA [m/s $\left.{ }^{2}\right]$ & 0.06 & $>0.063$ & Correct \\
\hline Motorway: RPA [m/s $\left./ \mathrm{s}^{2}\right]$ & 0.06 & $>0.025$ & Correct \\
\hline
\end{tabular}

The specified test route fulfils the requirements imposed by the legislator. It supplements the WLTC test procedure. The test route is characteristic for Warsaw and allows for conducting studies on emissions consistent with the requirements of the prevailing WLTC procedure.
Table 4. RDE test parameters - test example (fulfilled test)

\begin{tabular}{|c|c|c|c|}
\hline \multicolumn{4}{|c|}{ Test accuracy } \\
\hline Test parameter & Result & Requirement & Correctness \\
\hline Urban route $[\mathrm{km}]$ & 32.51 & $>16$ & Correct \\
\hline Rural route $[\mathrm{km}]$ & 28.42 & $>16$ & Correct \\
\hline Motorway route $[\mathrm{km}]$ & 29.21 & $>16$ & Correct \\
\hline Overall route $[\mathrm{km}]$ & 90.14 & $>48$ & Correct \\
\hline Urban share [\%] & 36.06 & $29-44$ & Correct \\
\hline Rural share [\%] & 31.53 & $33 \pm 10$ & Correct \\
\hline Motorway share [\%] & 32.41 & $33 \pm 10$ & Correct \\
\hline $\begin{array}{l}\text { Average speed in urban } \\
\text { route }[\mathrm{km} / \mathrm{h}]\end{array}$ & 33.29 & $15-40$ & Correct \\
\hline $\begin{array}{l}\text { Share of downtime } \\
\text { in urban route [\%] }\end{array}$ & 13.54 & $6-30$ & Correct \\
\hline $\begin{array}{l}\text { Trip time above } \\
100 \mathrm{~km} / \mathrm{h} \text { [min] }\end{array}$ & 14.57 & $>5$ & Correct \\
\hline $\begin{array}{l}\text { Max. driving speed } \\
{[\mathrm{km} / \mathrm{h}]}\end{array}$ & 128.00 & $<160$ & Correct \\
\hline $\begin{array}{l}\text { Trip time above } \\
145 \mathrm{~km} / \mathrm{h}\end{array}$ & 0.00 & $<3$ & Correct \\
\hline Duration of trip [min] & 97.95 & $90-120$ & Correct \\
\hline \multicolumn{4}{|c|}{ Dynamic test conditions } \\
\hline $\begin{array}{l}\text { Urban: number of data } \\
a>0.1 \mathrm{~m} / \mathrm{s}^{2}\end{array}$ & 1039 & $>150$ & Correct \\
\hline $\begin{array}{l}\text { Rural: number of data } \\
a>0.1 \mathrm{~m} / \mathrm{s}^{2}\end{array}$ & 393 & $>150$ & Correct \\
\hline $\begin{array}{l}\text { Motorway: number of } \\
\text { data a }>0.1 \mathrm{~m} / \mathrm{s}^{2}\end{array}$ & 309 & $>150$ & Correct \\
\hline $\begin{array}{l}\text { Urban: average speed } \\
{[\mathrm{km} / \mathrm{h}]}\end{array}$ & 33.29 & & \\
\hline $\begin{array}{l}\text { Rural: average speed } \\
{[\mathrm{km} / \mathrm{h}]}\end{array}$ & 71.54 & & \\
\hline $\begin{array}{l}\text { Motorway: average } \\
\text { speed }[\mathrm{km} / \mathrm{h}]\end{array}$ & 112.84 & & \\
\hline $\begin{array}{l}\text { Urban: } 95^{\text {th }} \text { centile } \\
\text { v. } a_{\text {pos }}\left[\mathrm{m}^{2} / \mathrm{s}^{3}\right]\end{array}$ & 13.92 & $<18.968$ & Correct \\
\hline $\begin{array}{l}\text { Rural: } 95^{\text {th }} \text { centile } \\
\text { v.a } a_{\text {pos }}\left[\mathrm{m}^{2} / \mathrm{s}^{3}\right]\end{array}$ & 18.36 & $<24.170$ & Correct \\
\hline $\begin{array}{l}\text { Motorway: } 95^{\text {th }} \text { centile } \\
\text { v. } a_{\text {pos }}\left[\mathrm{m}^{2} / \mathrm{s}^{3}\right]\end{array}$ & 18.60 & $<27.338$ & Correct \\
\hline Urban: RPA [m/ $\left./ \mathrm{s}^{2}\right]$ & 0.14 & $>0.122$ & Correct \\
\hline Rural: RPA [m/ $\left.\mathrm{s}^{2}\right]$ & 0.07 & $>0.061$ & Correct \\
\hline Motorway: RPA [m/s $\left.{ }^{2}\right]$ & 0.08 & $>0.025$ & Correct \\
\hline
\end{tabular}

\section{Summary}

Further RDE tests along the outlined route shall be performed to compare the results obtained from the Averaging Window Method and from other methods of determining exhaust emissions in on-road tests, i.e. the method using all measurement data and power binning method.

\section{Nomenclature}

BEV Battery Electric Vehicle

EV Electric Vehicle

FCEV Fuel Cell Electric Vehicle

NEDC New European Driving Cycle
RDE Real Driving Emissions

WLTP Worldwide harmonised Light Duty Vehicle Test Procedure

\section{Bibliography}

[1] Commission Regulation (EU) 2016/427 of 10 March 2016 amending Regulation (EC) No 692/2008 as regards emissions from light passenger and commercial vehicles (Euro 6).

[2] Commission Regulation (EU) 2016/646 of 20 April 2016 amending Regulation (EC) No 692/2008 as regards emissions from light passenger and commercial vehicles (Euro 6)
[3] Commission Regulation (EU) 2017/1154 of 7 June 2017 amending Regulation (EU) 2017/1151 supplementing Regulation (EC) No 715/2007 of the European Parliament and of the Council on type-approval of motor vehicles with respect to emissions from light passenger and commercial vehicles (Euro 5 and Euro 6) and on access to vehicle repair and maintenance information, amending Directive 2007/46/EC 
of the European Parliament and of the Council, Commission Regulation (EC) No 692/2008 and Commission Regulation (EU) No 1230/2012 and repealing Regulation (EC) No 692/2008 and Directive 2007/46/EC of the European Parliament and of the Council as regards real-driving emissions from light passenger and commercial vehicles (Euro 6)

[4] Commission Regulation (EU) 2018/1832 of 5 November 2018 amending Directive 2007/46/EC of the European Parliament and of the Council, Commission Regulation (EC) No 692/2008 and Commission Regulation (EU) 2017/1151 for the purpose of improving the emission type approval
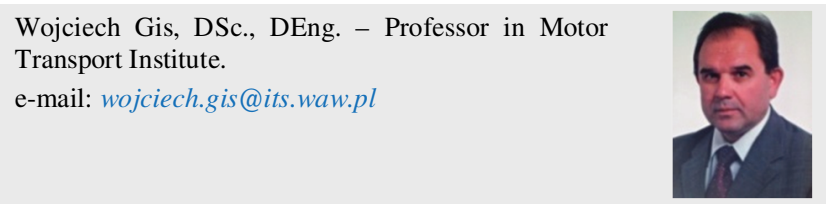

Prof. Jacek Pielecha, DSc., DEng. - Faculty of Transport Engineering, Poznan University of Technology.

e-mail: jacek.pielecha@put.poznan.pl

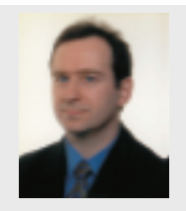

Maciej Gis, DEng. - Environment Protection Centre, Motor Transport Institute.

e-mail:maciej.gis@its.waw.pl tests and procedures for light passenger and commercial vehicles, including those for in-service conformity and realdriving emissions and introducing devices for monitoring the consumption of fuel and electric energy

[5] MERKISZ, J., PIELECHA, J. Selected remarks about RDE test. Combustion Engines. 2016, 166(3), 54-61.

[6] MERKISZ, J., PIELECHA, J., JASIŃSKI, R. Remarks about real driving emissions tests for passenger cars. Archives of Transport. 2016, 39(3), 51-63.

[7] Product Guide, AVL Gas PEMS, AVL List GmbH, Graz 2012.

Prof. Jerzy Merkisz, DSc., DEng. - Faculty of Transport Engineering, Poznan University of Technology.

e-mail: jerzy.merkisz@put.poznan.pl

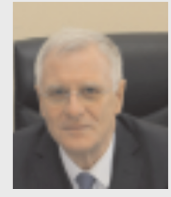

Prof. Stanisław Kruczyński, DSc., DEng. - Environment Protection Centre, Motor Transport Institute. e-mail: stanislaw.kruczynski@its.waw.pl
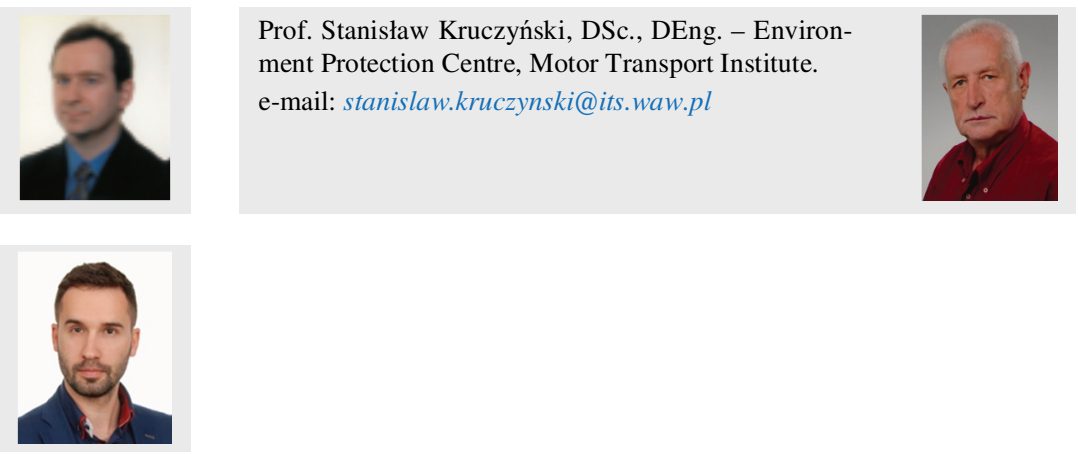